\title{
The Rise of "Localism" and Civic Identity in Post-handover Hong Kong: Questioning the Chinese Nation-state
}

\author{
Sebastian Veg ${ }^{*}$
}

\begin{abstract}
While it was traditionally accepted that Hongkongers shared a form of panChinese cultural identification that did not contradict their local distinctiveness, over the last decade Hong Kong has seen the rise of new types of local identity discourses. Most recently, "localists" have been a vocal presence. Hong Kong has - quite unexpectedly - developed a strong claim for selfdetermination. But how new is "localism" with respect to the more traditional "Hong Kong identity" that appeared in the 1970s? The present study takes a two-dimensional approach to study these discourses, examining not only their framework of identification (local versus pan-Chinese) but also their mode of identification (ethno-cultural versus civic). Using three case studies, the June Fourth vigil, the 2012 anti-National Education protest and the 2014 Umbrella movement, it distinguishes between groups advocating civic identification with the local community (Scholarism, HKFS) and others highlighting ethnic identification (Chin Wan). It argues that while local and national identification were traditionally not incompatible, the civic-based identification with a local democratic community, as advocated by most participants in recent movements, is becoming increasingly incompatible with the ethnic and cultural definition of the Chinese nation that is now being promoted by the Beijing government.
\end{abstract}

Keywords: Hong Kong identity; localism; civic nationalism; cultural nationalism; June Fourth vigil; Umbrella movement; National Education

Hong Kong's identification with the Chinese nation-state has been the subject of much discussion for over a century. Some of these debates are grounded in the ambiguous nature of the Chinese nation-state itself, others are connected to Hong Kong's distinctive historical path. As a British colony that had previously been a part of successive Chinese empires, Hong Kong cultivated a form of pan-Chinese cultural identification, which the colonial authorities tried to both foster and shape by placing a strong emphasis on a depoliticized form of 
traditional Confucian culture in the interwar period and again in the early 1950s. ${ }^{1}$ After 1949, the political representation of China was further contested, with mutually exclusive claims, made respectively by the Kuomintang (KMT) and Chinese Communist Party (CCP) governments, that only the Republic of China or the People's Republic of China (PRC) was the legitimate expression of the Chinese nation. While individual Hongkongers sometimes identified with one of these national communities, Hong Kong as a whole remained committed to a China defined by a community of culture. This held true even when the PRC gained international legitimacy in the 1970s and entered into negotiations for the handover of Hong Kong in the 1980s.

A distinct local identity, Heunggongyahn 香港人 (“Hongkongers"), rooted in consumerism and Cantonese pop culture, emerged in the 1970s. ${ }^{2}$ This identification has been variously described as "Chineseness plus," "market-based identity" or "sunshine patriotism,"3 and more recently as "liberal patriotism." never seen as being in conflict with "a profound consciousness of cultural and even 'racial' Chineseness." 5 Although Hong Kong was not apolitical in the 1970s, political movements (for instance, Chinese as an official language, protecting the Diaoyu Islands 釣魚島) were generally connected to a pan-Chinese cultural identification. ${ }^{6}$ In the 1980 s, this connection to China translated into the “democratic reunification” (minzhu huigui 民主回歸) agenda which advocated Hong Kong's "return" with a view to democratizing China. ${ }^{7}$ In 1997, Gordon Mathews fully expected that "heunggongyahn [would] fade into history," perhaps making China more liberal. ${ }^{8}$ Hence, expectations were high in Beijing that identification with the Chinese nation as a political entity would strengthen after the 1997 handover, especially among younger generations, eventually solving the problem of Hong Kong's full integration with China. Indeed, this expectation was implicit in the conditionality introduced into the Basic Law for the further democratization of Hong Kong.

In recent years, however, Hong Kong's identification with China has come under renewed scrutiny. Polls show that it is precisely the generation born around 1997 and educated after the handover that identifies the least with the Chinese nation, or even rejects it outright. This is connected with a series of events and social movements. Beginning with the anti-Article 23 protest in 2003, the patriotism debate in 2003-2004, the cultural heritage protection campaigns of 2004-2010, and the anti-National Education protests in 2012, Hong Kong has

1 Luk 1991; Law 2009, 107.

2 Mathews 1997; Ma, Eric Kit-wai 1999; Vickers 2003, 57-77.

3 Respectively, Mathews 1997; Mathews, Ma and Lui 2008, 12, 37, 92.

4 Chan, Elaine, and Chan 2013.

5 Vickers and Kan 2003, 188.

6 Lam 2004, 4, 156.

7 Hongkongers were never consulted on the future status of their territory and were excluded from the Sino-British negotiations. Survey Research Hong Kong (1982) suggests they massively favoured the status quo.

8 Mathews 1997, 13. 
increasingly asserted itself as a civic and cultural community. Contrary to the Heunggongyahn identity, the new discourse construes identification as a Hongkonger as contradictory with cultural or ethnic Chineseness. Polls show a disconnect between the two identities beginning around 2008 with a breakdown of the statistical correlation between Chinese and Hong Kong identification, and a majority of 18-29-year-olds identifying exclusively with Hong Kong from 2012. ${ }^{9}$ Moreover, pride in non-political symbols of China such as the Great Wall has collapsed since 2010. ${ }^{10}$

The new discourses on Hong Kong identity almost always refer to the notion of localism (bentulbuntou 本土). Before shooting to media fame in early 2016, the term first experienced a revival in the 2000s in connection with the heritage preservation (baoyu 保育) movement, whose activists fought to protect not Chinese high culture (temples, archaeological sites) but mundane sites rooted in the everyday life of Hongkongers, for example Lee Tung Street in Wanchai where wedding cards were made and the Star Ferry Pier, a daily commuter venue. ${ }^{11}$ In the context of China's rising economic and political clout after 2008, which impacted daily life in Hong Kong through tourism, parallel trading, real estate speculation and growing income disparities, local identity discourse embraced a "postmaterialist" critique of capitalism and colonialism, rejecting market identity, ${ }^{12}$ and paternalistic or authoritarian values like nationalism. ${ }^{13}$ The term localism was then taken up by writers like Chin Wan 陳雲 who developed an ethnic theory of Hong Kong's difference, ${ }^{14}$ and the student journal Undergrad (Xueyuan 學苑), which paired localism with the controversial notion of a "Hong Kong people/ nation” (minzu 民族) in a 2014 headline. ${ }^{15}$

How new, then, is localism, and how to define it? Previously, Hongkongers were consistently considered as (a) "culturally Chinese," and (b) politically committed mainly or strongly to pan-Chinese issues (Chinese as an official language, the Diaoyu Islands, the June Fourth vigil, democracy in China), while their growing identification with Hong Kong (consumer identity, pop culture) remained overall unpolitical and compatible with ethnic and cultural Chineseness. Liberal values like the rule of law or human rights were considered part of the Heunggongyahn identity, but generally connected to a well-functioning market or a well-run administration rather than to a political identity as a citizen. Today, it appears that the reference to a (real or imagined) Chinese nation-state is no longer hegemonic in Hong Kong. On the contrary, recent debates raise the

9 HKUPOP. 2016. "National issues. People's ethnic identity," https://www.hkupop.hku.hk/english/ popexpress/ethnic/eidentity/poll/datatables.html. Accessed 27 February 2017.

10 CUHK. 2014. "The identity and national identification of Hong Kong people. Survey results," http:// www.com.cuhk.edu.hk/ccpos/en/research/Identity_Survey\%20Results_2014_ENG.pdf. Accessed 7 February 2017.

$11 \mathrm{Ku} 2012$; Ip 2010.

$12 \mathrm{Ku} 2012,20$

13 Ma, Ngok 2011, 705.

14 Chin 2011

15 Undergrad Editorial Board 2015. 
question to what extent, contrary to expectations, members of the new generation (a) reject cultural Chinese identity and (b) identify as citizens with Hong Kong as a political community.

\section{Argument and Methodology}

The growing disconnect between a democratic local community and the nation-state suggests the need to disaggregate the new localist discourse in terms of cultural/ethnic and civic identity. This well-known distinction, derived from Ernest Renan, contrasts a civic identification model based on historic territory, laws and institutions, civic rights and duties, with an ethnocultural model based on (presumed) descent, language and customs. ${ }^{16}$ Racial representations play a strong role in the ethnic model, and often appear in assertions of pan-Chinese identity. ${ }^{17}$ Nonetheless, it should be emphasized that the distinction between the two models is an analytical one and that most empirical discourses of nationalism combine elements of both. ${ }^{18}$ The connection between Hong Kong's thwarted struggle for democracy within the "one country two systems" framework and the emergence of an "imagined community," on which the claim for democracy is now based, highlights the importance of civic identity in defining localism. This paper will therefore argue that the shift from pan-Chinese to a stronger localist identification is underpinned by a shift from an ethnocultural mode to a civic mode of identification, or a growing disconnect between the two.

The present study focuses primarily on the new discourses that openly challenge identification with the Chinese nation, following Craig Calhoun's description of nationalism as a "discursive formation," although socio-economic factors will be mentioned where relevant. ${ }^{19}$ Since identification is known to change with "salient events," 20 the present article, after examining the reappearance of bentu around 2006, discusses three events which provided the opportunity to mobilize bentu in public debates: the revival and localization of the June Fourth vigil from 2009; the anti-National Education movement in 2012; and the Umbrella movement in 2014.

The discussion uses texts produced by participants, media reports and available survey data as well as a small number of in-depth interviews (six in total) with prominent activists of the post-handover generation. The discussion of each of the events will be refined by contrasting different modes of identification (civic vs ethnic or cultural) and different communities of identification: "pan-Chinese" (da Zhonghua 大中華) and "local" (bentu). This two-pronged approach is summarized in Figure 1. 


\section{Figure 1: Local versus Pan-Chinese Identification}

\begin{tabular}{lll}
\hline $\begin{array}{l}\text { Framework of reference vs } \\
\text { mode of identification }\end{array}$ & Pan-Chinese 大中華 & Local 本土 \\
Ethnic; cultural & $\begin{array}{l}\text { Traditional cultural } \\
\text { nationalism; ethnic } \\
\text { nationalism (1) }\end{array}$ & $\begin{array}{l}\text { HK or Cantonese } \\
\text { chauvinism, nativism, anti- } \\
\text { mainland xenophobia (3) }\end{array}$ \\
Civic & $\begin{array}{l}\text { KMT } \\
\text { Democracy Movement (2) }\end{array}$ & $\begin{array}{l}\text { Democratic federalism, local } \\
\text { autonomy, } \\
\text { Scholarism/Demosisto (4) }\end{array}$
\end{tabular}

At first sight, localism is a confusing galaxy of ideas. While these ideas are based to varying degrees on prioritizing local over national identification, a distinction should be drawn between discourses claiming identification with Hong Kong on an ethnocultural basis and groups who affirm the civic nature of their identification with the territory. Neither type of identification can be easily reconciled with the previous understanding of a local identity grounded in consumerism and pop culture, and both challenge the connection to China. The proposed typology contains four combinations, which should be seen as non-exclusive ideal-typical categories. In modern Chinese history, local and national identities were not generally perceived as exclusive or contradictory. Some of the Hong Kong "localists" who phrase their claims in an ethnocultural mode (group 3) are also pan-Chinese nationalists (for example, Chin Wan). Similarly, some people who assert a civic identification with a pan-Chinese community (group 2; for example, June Fourth vigil participants) are also proponents of federalism or local autonomy (group 4). But they may increasingly reject a pan-Chinese identification in ethnic-cultural terms (group 1). Hence, the new "localist" identity may still intermittently overlap with a pan-Chinese civic community (2), but increasingly reject a pan-Chinese ethnocultural identity (1), which was previously seen as defining of Hong Kong. This is significant because the CCP has at the same time increasingly emphasized ethnocultural identification in its self-legitimizing discourse, incorporating traditional culture and Confucian concepts and extolling blood ties. While Hong Kong nativists or ethnic localists (3) have established a noisy presence, their philosophical proximity with pan-Chinese nationalists (1) makes them unattractive to many proponents of Hong Kong identity, who cast their identification in civic terms (4), rejecting the essentialism implicit in defining themselves as an ethnic nation.

\section{The Revival of Bentu}

The word bentu remains hard to translate. The notion of "indigenization" (bentuhua 本土化) existed as early as the 1970s and referred to the adaptation of colonial practices to the local environment. The term bentupai 本土派 ("local faction") was used in the 1980s by activists who favoured a more important 
role for local society in the handover. Bentuhua was also available as a category in Taiwan, where the rise of an "indigenous" faction (the usual translation in the Taiwan context) accompanied democratization: Lee Teng-hui 李登輝 is sometimes quoted as saying that "Democratization is precisely Indigenization." 21 The "strategic essentialism" that consisted in defending the rights of native Taiwanese (benshengren 本省人) by highlighting ethnic differences among the "four ethnic groups" left permanent traces in Taiwan's politics, so that A-Chin Hsiau asks whether Taiwan can move from indigenization to a more civic nationalism. $^{22}$ By contrast, several years later, Frank Muyard notes that democratic claims ultimately allowed the civic definition of the nation to prevail in Taiwan. ${ }^{23}$ In Hong Kong, the word has also evolved from a broader meaning in the mid-2000s to a more narrow and "nationalistic" one today.

As noted above, discussions about Hong Kong cultural identity pre-dated 1997. In the aftermath of the 2003 events, and the inception of the heritage protection movement in Lee Tung Street in 2004, calls for "decolonization" began to emerge. Local Action, a loose group founded in late 2006 by academics, journalists and student activists to fight for the preservation of the Star Ferry and Queen's piers, revived the term bentu in its Chinese name, Bentu xingdong 本 土行動. ${ }^{24}$ In 2008, a group of well-known local academics and commentators, in conjunction with the liberal think-tank Synergy, published a book entitled Bentu lunshu 本土論述 (Journal of Local Discourse), presented as a yearly journal and edited by three journalists with an inclination towards the humanities. ${ }^{25}$ This group presented themselves as "left-wing localists": left-wing in the sense that they are critical of capitalism and the post-colonial situation of Hong Kong. They are also deemed to be sympathetic to people persecuted in the mainland and opposed to anti-mainland xenophobes (who could more precisely be called “nativists" in English). ${ }^{26}$ In the inaugural issue, Leung Man-to 梁文道 connects bentu with the heritage preservation movement, subaltern memories, and opposition to the post-colonial and neo-liberal city. ${ }^{27}$ In this way, the meaning of localism was tied to social agendas critical of "real-estate hegemony," elite collusion between Hong Kong and Chinese tycoons, and "crony capitalism" (quangui zibenzhuyi 權貴資本主義). ${ }^{28}$

On the other hand, in late 2011, Chin Wan, a little-known academic, cultural critic and former government employee with a $\mathrm{PhD}$ in folklore from the University of Göttingen, published Theory of the Hong Kong City-state

21 Lee, Teng-hui 2001.

22 Hsiau 2005, 273.

23 Muyard 2012.

24 Ip 2010.

25 Ma, Ka-fai, Leung and Wong 2009.

26 There is some ambiguity in the use of "left-wing" in Hong Kong, where it often refers to pro-PRC positions. I have tried to limit it to its more classical sense of "socially critical" to avoid confusion, and use "pro-CCP" or "pro-China" instead when appropriate.

27 Bentu lunshu 2009, 7-8.

28 Lee, Yee 2013. 
(Xianggang chengbang lun 香港城邦論). ${ }^{29}$ In his biography printed in the volume, he underlines his Hakka roots in Bao'an 寶安, Guangdong, his rural upbringing (his father fled the anti-rightist movement to come to Hong Kong), and overseas Chinese ancestry in South-East Asia. Critiquing the economic subordination of Hong Kong to China brought about by free-trade agreements, he mainly advocates putting Hong Kong's interests first: "Hong Kong has priority, Hong Kong is number one [in English], Forget China, Hong Kong comes first." 30 Taking note of the indefinite postponement of the democratization of China, he breaks with the "democratic reunification" rhetoric and proposes to "not wait" for China's democratization to pursue democracy in Hong Kong. ${ }^{31}$

Chin contributed an article to the Journal of Local Discourse in which he highlights the "conflicting interests" between Hong Kong and China. He describes a "recolonization" of Hong Kong by China after the handover, which is made worse by the fact that China, unlike the UK, is not itself a law-abiding democracy. Citing recent immigration (mainland mothers giving birth in Hong Kong) and welfare issues, he asks whether new immigrants are prepared to support democracy in Hong Kong, and concludes that the "locust invasion debate" has "unexpectedly sparked a discussion on the principles of citizenship underpinning welfare policy, as well as precipitated the formation of Hong Kong's ethnic conscience (zuqun yishi 族群意識) and city-state conscience, and of an agenda for self-rule and autonomy (zizhu zizhi 自主自治).” At the end of the article, he sets out a five-point agenda for "city-state self-rule": it must preserve the unique cultural mix of Hong Kong, including imperial Chinese and Western influences; it must recognize the diverging long-term interests between Hong Kong and China and enshrine autonomy, even if the latter democratizes; it must preserve the "authentic" Chinese culture "destroyed" by the CCP (Cantonese language and its "antique" pronunciation; non-simplified characters); it must preserve Hong Kong from the coming collapse of China; and, in the long term, it should promote the formation of a "Chinese commonwealth" (Zhonghua banglian 中華 邦聯) of Hong Kong, China, Taiwan and Macau, opening a "Chinese world order" (Zhonghua tianxia 中華天下). ${ }^{32}$

Chin Wan's central preoccupations are complex. While he defines bentu mainly in the sense of a prioritization of Hong Kong's interests, cast in ethnic terms (zuqun yishi), his deeper agenda is a pan-Chinese one, as his vocabulary (for example, his use of tianxia) shows. His endorsement of Hong Kong is part of an ethnic definition of the Chinese nation that excludes communism and the current regime in mainland China, whose citizens he calls "strong-country people" (qiangguo ren 強國人), not unlike early KMT intellectuals (who called them “bandits"). He does not favour independence but “restoration" ( fubi 復辟). ${ }^{33}$

29 Chin 2011.

30 Ibid., back cover.

31 Ibid.

32 Chin 2012, 189; 2015.

33 Kuang 2013, 62, 63. 
However, he does not advocate democracy for China today, as he believes it will negatively impact Hong Kong. This reverses the mainstream position among the pro-democracy forces who generally support the joint democratization of China and Hong Kong. His endorsement of Cantonese is grounded in the widespread argument that it is a "purer" form of the Chinese language, uncontaminated by both invasions from the north and communist politics. In many ways, he is a classic pan-Chinese ethnic nationalist with a localist touch.

His ideas, widely disseminated on Facebook and often couched in flowery, traditional language, were appropriated and reinterpreted by a nebula of splinter groups waving various "local" flags. ${ }^{34}$ One group, Hong Kong Indigenous (Bentu minzhu qianxian 本土民主前線), rose to fame in February 2016 when their candidate was involved in violence in Mong Kok 旺角 and, advocating selfdetermination (zijue 自決), gained 15 per cent of the vote in a by-election; he was later disqualified from the September 2016 LegCo election. Chin's more xenophobic ideas were separately adopted by groups such as Hong Kong Priority (Xianggang ren youxian 香港人優先) and Civic Passion (Rexue gongmin 熱血公民), members of which appeared at the anti-parallel trader protests that developed in 2014 and have attacked moderate pan-democrats. Chin's ideas have also proved attractive to a wide range of people, as they chime with a pervasive frustration with China's policy towards Hong Kong, a frustration that stems from rising economic inequalities, in particular the lack of opportunities in China, soaring real estate prices linked to the influx of Chinese capital, and the mainland's encroachment on Hong Kong's autonomy. ${ }^{35}$

Chin's book popularized the notion of "localism" and a new ethnocultural discourse that challenges Hong Kong's cultural connection with China. However, these ideas were only a starting point or a catalyst for a wider and more positive form of identification. As one student activist put it:

In 2012 was the beginning of Chin Wan and the Hong Kong city-state theory ... China began to be seen as the other, but most important is the positive identification with Hong Kong and collective memories ... Building an identity and a subjectivity was a very important part of the movement ... Hong Kong nationalism will become more popular and powerful if the degree of autonomy is continually lowered by the CCP. Under those conditions, even without international support, Hong Kong independence will still be supported by many Hong Kong people. $^{36}$

Chin's book launched the process of conceptualizing what activists began calling a Hong Kong "subjectivity” (zhutixing 主體性), as opposed to the "lifestyle" identity of previous decades. Based on collective memories and political struggles over the following years, this subjectivity is viewed by some as the starting point for the development of Hong Kong as a separate political entity.

34 For example, Hong Kong Autonomy Movement, Hong Kong Indigenous, and the Hong Kong National Party.

35 See Lui 2014; Wong, Stan 2015; Yuen 2014.

36 Interview with former Undergrad editor A, 25 March 2015. 


\section{The "Localization" of June Fourth: Affirming Civic Values}

The evolution of the June Fourth vigil encapsulates the complexities of national identification in Hong Kong. The events of 1989 represented the possibility of fulfilling both decolonization and "democratic reunification," solving the problem of Hong Kong's status by achieving democracy in Hong Kong through a return to a democratic China. The crackdown, however, triggered a protest march of over a million people and mass emigration in the years running up to the handover. The vigil was traditionally seen as a rallying point for a civic valuebased pan-Chinese identification that characterized the older generation of prodemocracy activists and which was the epitome of "democratic reunification." 37 The vigil was also seen as a typical example of "liberal patriotism," combining culture-based pan-Chinese nationalism (morally improving the abstract Chinese nation by making it democratic) and Hong Kong's specific liberal culture of protest. It provided a prominent platform for slogans that emphasized Hong Kong's role in strengthening the nation as well as songs with nationalistic overtones. Even the organizers' name (Hong Kong Alliance in Support of Democratic Patriotic Movements of China, or "the Alliance") asserts Hongkongers' right to claim "patriotism" for themselves (just as the KMT has done for a long time). This identification has unexpectedly become controversial in recent years.

In retrospect, the 20th anniversary of the crackdown in 2009 marked a turning point. First, turnout figures, which had dwindled, increased massively and unexpectedly, reaching 150,000 that year, and then 200,000 in 2012 and 2014. ${ }^{38}$ Participants in the vigil before 2009 were predominantly older, whereas from 2009 onwards, the majority were under 30, many of them born after 1989. However, this revival was not immediately localist. As Joshua Wong 黃之鋒 told an interviewer in 2012, "I believe that we express our love for China through the June Fourth vigil. I hope China can improve, and we take part in June Fourth every year to express Hong Kong's feelings for China. Hongkongers hope that China will be democratic, Hongkongers care about China." 39 In fact, Wong devoted his first two published articles to the June Fourth events. In the first one, he discusses "civil disobedience" (gongmin kangming 公民抗命) as a technique inspired by the Tiananmen 天安門 protesters (the idea was popularized by Benny Tai 戴耀廷 two years later). ${ }^{40}$ In the second one, he wrote:

seeing that among the 1.3 billion people of the motherland, only 7 million of us have the right to commemorate the dead of June Fourth, one can't help reminding oneself to treasure Hong Kong's freedom of expression and religion, to maintain Hong Kong's superiority and identity, Hong Kong must take the responsibility of being a base for advancing the cause of democracy on the mainland, reconquer the mainland ( fangong dalu 反攻大陸), fight for democracy for our compatriots (tongbao 同胞). ${ }^{41}$

37 Lee, Francis, and Chan 2011, 184.

38 All attendance figures as given by the Alliance. See $\mathrm{Ng}$ et al. 2015.

39 Huang 2012.

40 Wong, Joshua 2011a.

41 Wong, Joshua 2011b. 
At this stage, Wong espoused the traditional discourse on the June Fourth events as primarily related to democracy in China, emphasizing "responsibility" and even using the KMT's notion of "reconquest" (fangong 反攻) and the ethnic term tongbao.

What triggered this awareness among the new generation? A controversial documentary on Tiananmen broadcast by ATV sparked a heated debate on the Hong Kong Golden internet forum. ${ }^{42}$ Social media, in particular Facebook and Hong Kong Golden, were instrumental. ${ }^{43}$ Joshua Wong, who attended the vigil for the first time in 2010, cited the crackdown on human rights in China, comments made by the Hong Kong chief executive, and a liberal studies programme which raised awareness about June Fourth among students as reasons for the increased awareness. ${ }^{44}$ The "China factor" certainly played a role: 2008-2009 was a turning point in the central government's more restrictive approach to civil society. However, for Wong and others, it seems that attendance at the vigil first occurred within the traditional pan-Chinese framework, just one year after a peak of "patriotic" feeling during the Beijing Olympics.

After 2009, a shift took place. Concerns about China's human rights situation surged but, in parallel, Hongkongers' sense of "responsibility" for China shows a linear decline, from 84 per cent in 1993 to 66 per cent in $2015 .{ }^{45}$ Younger cohorts are prepared to protest against China's human rights abuses (as citizens of the world), but not to consider that these abuses are committed by their own society or group. Support for democracy in China remains high; however, the notion of ethno-cultural solidarity is increasingly questioned.

In this way, the commemoration of June Fourth gradually came to be reinvented as a local event. Younger cohorts who had joined the vigil within the traditional framework of "liberal patriotism" in 2009 rapidly became critical of this framework, but remained mobilized within the vigil, as shown by events in 2013 and 2015. When, in 2013, the Alliance put forward the slogan, "Love the country, love the people: the Hong Kong spirit" (Ai guo ai min, Xianggang jingshen 愛 國愛民香港精神), younger participants voiced their strong opposition to the idea of "patriotism" (aiguo 愛國) and eventually the Alliance had to drop the slogan. ${ }^{46}$ This unprecedented criticism of the inclusion of "patriotism," which was one of the foundations of the vigil, was formulated in the name of universal

42 Informal interview with activist, 2 March 2015. See also "Yashi bo liusi cheng fengbo, Shenzhen chouqi min'gan zhuanji" (ATV show calls June Fourth disturbance, Shenzhen pulls sensitive special series), Mingpao, 24 May 2009. HK Golden is considered a gathering place for the young, male "otaku" or "nerd" culture, where discussions mainly focus on sex and local politics.

43 "Liusi ye zhuguang, jinnian geng mingliang" (June Fourth vigil candlelight, brighter this year), Open Magazine, June 2009, http://www.open.com.hk/old_version/0906p29.html. Accessed 27 February 2017.

44 Interview with Joshua Wong, 24 November 2015. Chief executive Donald Tsang declared during a LegCo session that the Hong Kong people had forgotten about June Fourth.

45 HKUPOP. 2015. "Survey on June Fourth incident," https://www.hkupop.hku.hk/english/features/june4/ june4.html. Accessed 27 February 2017.

46 Veg 2013. 
moral and political values; the vigil no longer served to articulate a democratic pan-Chinese identity.

Also in 2013, Chin Wan spoke out against the vigil (which he calls the "altar of demons”) and organized a rival event at Tsim Sha Tsui 尖沙咀. His analysis of the June Fourth vigil was grounded in hostility to the universal values embraced by the younger activists: "People whose impulse to act derives from universal values cannot achieve anything good. There are only two possible outcomes: hypocrisy or self-sacrifice." He went on to attack the three "universal values" of the French Revolution, liberty, equality, fraternity, and what he viewed as their selective application, as hypocritical. ${ }^{47}$ His parallel vigil did not attract many followers but his critique made many people think about their commitment.

In 2015, in the aftermath of the Umbrella movement, renewed discussion broke out among localists and supporters of the vigil as organized by the Alliance. Many now criticized its ritualization, like Joshua Wong: "The memory of June Fourth is very much alive. But you shouldn't overestimate its political meaning. The candle-lit vigils have become a kind of ritual. They are moved more by emotional pity for the victims of 1989 than by solidarity with their actions." ${ }^{\prime 4}$ The Hong Kong Federation of Students (HKFS) withdrew from the organizing committee of the event in Victoria Park. The Hong Kong University Student Union organized a parallel vigil at the university, which attracted about 2,000 people, citing its reluctance to endorse a clause in the HKFS charter which enshrines the "fight for a democratic China" as one of the Federation's goals. With Chin's vigil at Tsim Sha Tsui, Hong Kong now had three rival commemorations, although the one in Victoria Park remained very well attended, with an estimated turnout of 135,000, which was far more that pre-2009 attendance figures. ${ }^{49}$

This shift in interpretation of the June Fourth events is captured in surveys and in discourses. A poll conducted at the three sites in 2015 highlights the motivations of the new generation..$^{50}$ Their two main reasons for joining the vigil were to "Reverse the verdict on June Fourth" and "Obtain democracy for Hong Kong," while "Build a democratic China" enjoyed much weaker support. Significantly, when asked to rate separately the importance of each capacity in which they were attending the rally, 88 per cent rated attending "as Hongkongers" as important, only 9 per cent "as Chinese" and 43 per cent as "citizens of the world." The generational shift is clear in the age differences: "patriotism" was important to the majority of 50- to 64-year-olds, but unimportant to the majority of 18- to 29-year-olds; "democracy in China" was important to both, but far more to the older cohort. It is clear that the largest group from the new generation attending the rally saw themselves as Hongkongers opposing the official verdict on June Fourth and claiming democracy for Hong Kong. Second

47 Chin 2013.

48 Wong, Joshua 2015a, 46.

$49 \mathrm{Ng}$ et al. 2015

50 See Cheng and Yuen 2015a. I would like to thank the authors for sharing their survey data with me and allowing me to contribute to the drafting of some of the questions. 
were those who viewed themselves as citizens of the world backing democracy, and only third were those who saw themselves as Chinese citizens seeking to build a democratic China from Hong Kong.

Interviews with two student activists illustrate this point. One of the editors of Undergrad, retracing his connection with June Fourth, explained how he became a "localist." While his family, who emigrated from Guangdong during the Mao era, are critical of the CCP, they also "love China" and do not attend the vigil. He first attended the vigil in 2010 and felt a sense of community with China, a sense of Hong Kong's role in China, similar to that described in Joshua Wong's essay; however, in following years, this feeling faded:

The third time [in 2012], I went alone to reflect. You sing songs, watch videos and cry, but I felt hesitant about "building a democratic China." I have to act according to my beliefs; I hate utopian, humanistic visions. Are Hong Kong people really determined to build a democratic China? Most join the vigil and then have dinner with friends. It feels like such a distant dream. Like a drug. But no one is ready to make sacrifices for Chinese democracy. That night, I turned into a localist. I became critical of what Hong Kong people had been doing for so many years, critical towards Chinese democracy, cynical. I thought it was ok to participate to commemorate history, but others are hypocritical. I want to build a democratic Hong Kong first. Although I still respect those who really fight for democracy in China. But not those who use democracy in China as a pretext not to fight for democracy in Hong Kong. ${ }^{51}$

Another student leader from the HKFS, on the other hand, acknowledged a change in meaning but formulated it differently:

I first went to the vigil in 2008, then kept going every year. I'm fine with the vigil. After all, it's a vigil ... A vigil should not be a protest or something else ... It gives a black and white vision. It's an event that demonstrates the moral influence of the Hong Kong people, what should not be forgotten. In recent years, the meaning of June Fourth is being renewed. It can be taken as a model for democratic development in Hong Kong. ${ }^{52}$

These two accounts are very different. The first one is the epitome of "localist" discourse: it highlights the experienced "emptiness" of the pan-Chinese identification expressed in June Fourth commemorative events, compared to the moral authenticity of the connection to Hong Kong, typical of a nationalist commitment. The second one illustrates a different shift, from a pan-Chinese to a universalist commitment to the meaning of June Fourth, in which Hong Kong displays its "moral influence." But, while holding on to the relevance of the vigil, it also shares with the first account a commitment to democracy in Hong Kong. Here, the June Fourth vigil is reinvented as a "model for Hong Kong" rather than Hong Kong's liberalism being put forward as a model for China, and the moral authenticity of the commemoration binds the Hong Kong community together. This core idea is pervasive among the young cohorts who continue to attend the vigil, and it is no longer connected with pan-Chinese nationalism. In this respect at least, the "localist" and the "universalist" convictions are not as different as one might think. 
This evolution can also be seen in intellectual discourses, which fall into three categories. Chin Wan's view is somewhat confused: he opposes universal values and a civic identification with the Chinese nation based on democracy, and instead favours an ethno-cultural definition of the nation, which - depending on the occasion - does or does not extend to the whole of China. Liberal intellectuals (with a deeper attachment to China), such as Law Wing-sang 羅永生, describe the vigil as a manifestation of either the moral values that bind the Hong Kong community together ${ }^{53}$ or of Habermas's "constitutional patriotism," ${ }^{4}$ highlighting a civic commitment to both the Hong Kong and the pan-Chinese communities. Other, more (civic) "localist" intellectuals such as Hung Ho-fung 孔誥烽 discuss the need to both commemorate June Fourth and to criticize certain "pan-Chinese traditions" that contributed to the failure of the 1989 movement, such as the "loyal vassal mentality" which induced three students to kneel on the steps of the Great Hall of the People when presenting a letter to the Party leaders. ${ }^{55}$ This can be described as a civic identification primarily with the local community.

Altogether, a growing proportion of Hongkongers no longer associates the memory of 1989 with a sense of identification with China as a cultural nation, but rather with a universal moral principle, or a form of identification with Hong Kong, rarely ethnic (Chin Wan) and usually civic ("constitutional patriotism"). The younger cohorts feel a diminishing sense of responsibility for China: rather than a "national wound," they commemorate the inaugural trauma in the process leading up to the handover, the failure of "democratic reunification" and Hong Kong's as-yet unsuccessful fight for democracy. Their identification is with universal values (a growing concern for the human rights situation on the mainland) but is at the same time connected to a political sense of a local community. They are no longer participating in a national(ist) communion but in the affirmation of a specific community of commemoration. ${ }^{56}$

\section{The Anti-National Education Movement of 2012 and Scholarism: Opposing the Cultural-ethnic Definition of the Nation}

While the revival of the June Fourth vigil in 2009 may have initiated a generation's politicization, the anti-National Education movement that unfolded in the summer of 2012 marked its political coming of age and solidified its opposition to Chinese state-led ethnic nationalism. Without the direct involvement of any political party, the movement mobilized over 100,000 people, first to sign a petition, then to take part in a massive march on 29 July, and finally to

56 This, incidentally, also explains the greater relevance of June Fourth to Hong Kong in comparison with Taiwan, where rallies have remained much smaller despite the presence of former Beijing student leaders. 
participate in an eight-day sit-in at government headquarters. The movement had the broad support of public opinion and forced the chief executive to withdraw the project on 8 September 2012 on the eve of legislative elections. The movement was organized by the group Scholarism 學民思潮 (founded on 29 May 2011, just a few days before June Fourth) and its charismatic leader, Joshua Wong Chi-fung (born in 1996), along with over 20 other civic groups. ${ }^{57}$ It was directly triggered by the government's National Education curriculum project. ${ }^{58}$

It is worth briefly assessing the ideas that underpinned the movement. Chief executive C.Y. Leung 梁振英 had inherited the curriculum project from his predecessor, Donald Tsang 曾蔭權. In 2008, the Task Group on National Education set up by the government published a report that explicitly emphasized the cultural-ethnic definition of the nation. It suggested that the future National Education curriculum should highlight: "(1) racial ties, noting that we are all connected by blood as Chinese, sharing the same features of dark eyes, black hair, and yellow complexion; (2) culture and heritage, which refers to our sharing a wealth of long-established, profound cultural legacy of China, and (3) our country itself." 59 A similar policy initiative had been launched in the immediate aftermath of the 2003 anti-Article 23 protests, with the stepping-up of flag-raising, anthem-singing and the use of Mandarin. The new project seemed to stem from a realization that students educated after the handover (whose increased "patriotism" was originally supposed to make the implementation of universal suffrage possible) were in fact developing a stronger anti-Beijing stance than the previous generation.

Two aspects of the National Education project crystallized its opposition: the government's financial support to groups producing pro-Beijing teaching materials (cronyism and lack of respect of standard procedures) and the fear that students would be assessed on subjective criteria like "loyalty" (a state-prescribed identity). Joshua Wong highlighted this latter point in an interview: "We opposed the new curriculum because it was a blatant attempt at indoctrination: the draft course hailed the Communist Party of China as a 'progressive, selfless and united organization.' Secondary school students didn't want this kind of brainwashing."60

School curricula have been a sensitive subject in Hong Kong since the early colonial days. In a context in which most schools are run by religious congregations, charity institutions or, at the other end of the political spectrum, hometown associations linked with lineage networks or pro-China groups, any change involving the portrayal of the Chinese nation is potentially sensitive, in particular in Christian schools. Before the war, Confucian classics had been taught to combat the influence of May Fourth ideas. ${ }^{61}$ After the Second World War, history

57 For a detailed chronology of events, see Morris and Vickers 2015; Wong, Joshua 2015a.

58 Wong, Joshua 2012.

59 Task Group on National Education. 2008. Promotion of National Education in Hong Kong - Current Situation, Challenges, and Way Forward, 9, as quoted in Morris and Vickers 2015.

60 Wong, Joshua 2015a, 44.

61 Luk 1991. 
was taught in two separate subjects, with a sharp methodological split. A depoliticized, culturally conservative "Chinese history" subject was taught in Cantonese. With a slant towards antiquity and omitting contemporary politics, it was designed to "inoculate the territory against the formation of any political sense of nationhood - even while licensing the inculcation ... of a rather chauvinist sense of cultural 'Chineseness.".62 "World history," introduced in parallel, was taught in English. The two subjects were separate worlds in terms of methodology, with the former regarded as a "moral" discipline, ${ }^{63}$ an idea echoed in the title given to the 2012 project for "moral and national education" (deyu ji guomin jiaoyu 德育及國民教育). Throughout colonial times, this division was only occasionally questioned (for instance, by the likes of Szeto Wah 司徒華) but never rethought; indeed, the place of Chinese history was defended in two controversies in 1975 and 1999.64

By contrast, in 2012, the methodological exceptionalism of national education as moral was now seen as problematic and frontally challenged. The name chosen for the new subject deserves some analysis. While guomin 國民 has recently become a word for "citizen" in the PRC (as in Zhongguo guomin 中國國民 - "Chinese citizen" or "Chinese national"), it was, in the early 20th century, one of several competing translations for "nation" and was eventually displaced by minzu, which refers to a nation in the sense of an "ethnic group." 65 This nuance was explicit in the new name, which highlighted loyalty to the nation-state, in contrast with the notion of liberal citizenship, encapsulated in the earlier subject of "citizenship education" (gongmin jiaoyu 公民教育) that was introduced as part of the new liberal studies (tongshi jiaoyu 通識教育) curriculum in $2009 .{ }^{66}$ In particular, in one of the appendixes of the curriculum guide, emphasis was placed on kindling "passion" and "affection" by selecting appropriate material: "Teachers should develop students' affection for their country ... Teachers should enable students to understand that they share the same root with their country and are closely linked to their country in history, race and culture." 67 Rather than the rational engagement of the citizen, the guide promoted ethnic identification based on affect.

Most observers believe that the liberal studies subject introduced in 2009 furthered the cause of democracy and citizen awareness, coming together with the 20th anniversary of June Fourth as a generational marker to spread a civic

62 Vickers 2011, 101.

63 Kan 2007, 92.

64 In both cases, the subject was to be merged into a broader one, "social sciences" in 1975, "new history" in 1999 (ironically under C.H. Tung), and in both cases the government had to back down. Kan 2007, 140 and Vickers 2003, 197-228.

65 The original meaning (also retained in the Japanese reading kokumin) is still apparent in the name of the KMT, the "nationalist" party, in the standard English translation. This is how the new Hong Kong curriculum proposal came to be translated into English as "national" or "patriotic" rather than "citizen" education.

66 Chan, Cheuk-Fan 2012.

67 "Moral and national education curriculum guide," April 2012, http://www.edb.gov.hk/attachment/en/ curriculum-development/4-key-tasks/moral-civic/MNE\%20Guide\%20(ENG)\%20Final_remark_ 09102012.pdf, 149-150. Accessed 7 February 2017. 
understanding of citizenship. ${ }^{68}$ By contrast, "national education" suggested the central and SAR governments' will to strengthen the language of cultural and ethnic loyalty to the nation, a language that enjoyed support throughout the colonial era, in particular in the subject of Chinese history. Polls carried out in August 2012 showed that teaching more Chinese history and even highlighting positive aspects of PRC history were broadly supported. ${ }^{69}$ However, opposition hardened to "schools having a required subject of national education based on the government's curriculum guide": 28 per cent supported the move, 56 per cent opposed it; opposition rose to 71 per cent among 18-19-year-olds and 68 per cent among 20-29-year-olds. ${ }^{70}$ While the traditional cultural identity remained acceptable to most people, a state-prescribed version of it was not.

In conclusion, the opposition to the moral and national education curriculum is particularly remarkable in view of the strong support given to the similar subject of Chinese history throughout the colonial era and which resurfaced after 1997. It is true that the fear of being evaluated with respect to patriotic feeling had begun to emerge during the "re-education" efforts of the SAR government under C.H. Tung 董建華. ${ }^{71}$ However, the 2012 movement signals a deeper rejection of Hongkongers' identity as guomin ("nationals"), and an embrace of their identity as gongmin ("citizens"). Paul Morris and Edward Vickers see the anti-National Education protests as essentially the extension of previous assertions of Hong Kong's dual (Chinese and local) identity and the expression of the diversity of narratives of the Chinese nation..$^{72}$ The present article, in contrast, argues that the 2012 rejection of a previously uncontroversial ethnocultural Chinese identity, and the shift to a civic identity as a "citizen" of Hong Kong (gongmin) rather than of China (guomin), is significant. The younger generation opposed the central and SAR governments' programme to boost identification with the Chinese state, and also contested the cultural-ethnic definition of the Chinese nation inherent in it, preferring citizenship to the traditional moral notion of a cultural community.

The movement itself was a watershed in the development of Hong Kong society, as it was led by a group without political affiliations and without organic links with the pan-democrats. In the words of one of the Scholarism leaders:

Before 2012, to join the social movement, you needed to be left-wing and agree with ideas like "we are all equal" and "countries are not important" ... Scholarism tried to change this. Scholarism is diverse, from left to right. There are localists and a left wing ... The anti-National Education movement broke the traditional protest model and attracted the new generation of the post-90s. There was no need for a political affiliation to be part of the democratic movement. It awakened a generation. ${ }^{73}$

68 Yeung 2013.

69 Even Joshua Wong highlighted this (Huang 2012).

70 See HKTP. 2012. "Total recall. Issues and attitudes in the 2012 Hong Kong Legislative Council elections," http://www.hktp.org/list/total-recall-small.pdf, Tables 85-91. Accessed 27 February 2017.

71 Vickers and Kan 2003.

72 Morris and Vickers 2015.

73 Interview with former Scholarism leader, 23 March 2015. 
"Left-wing" here refers to both social ideals of equality and a general sympathy for China: the word is specifically used to criticize traditional pan-democrats for being too humanistic and therefore sympathetic to Chinese democrats. Scholarism is a forum for people who are sympathetic to Chinese democrats (the "left-wing" referred to above) as well as for "localists" whose political engagement is not necessarily universalistic and egalitarian but instead rooted in the defence of Hong Kong. As the interviewee concludes, its role in awakening a generation to politics was decisive.

\section{The Umbrella Movement and the Claim for Self-determination: Affirmation of a Local Civic Community}

The Umbrella movement, which lasted for 79 days during the autumn of 2014, marked a new development in the discussions about Hong Kong identity after a decade of activism. ${ }^{74}$ While the overwhelming focus of the movement was universal suffrage, identification with Hong Kong and expressions of "localist" discourse were well-represented within it. As early as 2013, Benny Tai described "Occupy Central with love and peace" as a "localist democratic movement" (bentu de minzhu yundong 本土的民主運動). ${ }^{75}$ In a widely quoted survey carried out on the three occupied sites in 2014, when given an open choice between five categories of self-proclaimed identity (Hongkongers, Chinese, two mixed or "other"), 81 per cent of the respondents identified themselves exclusively as Hongkongers. ${ }^{76}$

The movement was preceded and underpinned by discursive elaborations of local identity. In February 2014, the Hong Kong University Student Union's journal, Undergrad, published an issue under the headline: "The Hong Kong nation/people: deciding its destiny" (Xianggang minzu: mingyun zijue 香港民族: 命運自決). The editors advocated a debate about grounding Hong Kong's claim for autonomy in the redefinition of a civic community of Hong Kong citizens distinct from China.

Undergrad editor Kai Ping Leung's 梁繼平 article defines the nation by quoting theories by Renan (community of will) and Montserrat Guibernau (sovereignty lies with the people), then discusses the social contract and provision of welfare to members of a community of shared interests and obligations, arguing that Hong Kong should reserve its welfare benefits for members of the civic community, regardless of ethnic origin, in direct contrast with the discourse of ethnocultural solidarity with China. "The rise of civil society in recent years, the ethnic conflicts between Hongkongers and Chinese, the failure of the dream of democratic reunification, have all contributed to stimulating Hong Kong's local conscience (bentu yishi 本土意識). The great unitary nationalism of 'we are all Chinese' has already lost its currency, society is now reconstructing a Hong

74 Veg 2015; Cheng 2016.

75 Tai 2013.

76 Cheng and Yuen 2015b. 
Kong identity based on our subjectivity (zhutixing)." 77 Ethnic solidarity is now replaced by ethnic conflict with China, while local identification is defined by the rise of civil society and common "subjectivity." In fact, localist groups may be more amenable to integrating South and South-East Asians, perennial outcasts in Hongkongers' ethnocultural identification as Chinese, and indeed some South Asian groups asserted their active political participation in the Umbrella movement. ${ }^{78}$

Deputy editor Wong Chun-kit 王俊杰, drawing on Benedict Anderson, adds that "Hong Kong nationalism must steer clear of narrow racial nationalism, and use identification with values rather than with blood. In keeping with geography, history and other objective conditions, respecting the freedom of individual agreement, [we must] foster a kind of civic nationalism." ${ }^{79} \mathrm{He}$ defines these values mainly through democracy: "If nationalism means giving sovereignty or the right to govern to the people, then it is completely compatible with democracy or popular government." 80 The Hong Kong "nationalism" advocated in this publication is thus defined as civic and closely connected to the democratic participation of civil society in political decision making.

Although they did not appear in the four main demands made at the beginning of the Umbrella movement, the notions of "subjectivity" or "agency" (zhutixing), “autonomy” (zizhu 自主) and "self-determination” (zijue) became central themes of the debate during the occupation. ${ }^{81}$ Before the 31 August decision was published, the secretary of HKFS, Alex Chow 周永康, posted an online essay in which he called for a move "from democratic reunification to determining our own destiny" (you minzhu huigui dao mingyun zijue 由民主回歸到命運自決). ${ }^{82}$ The slightly attenuated version, "Masters of our own destiny" (mingyun zizhu 命運自主), became the slogan inscribed on the central stage at Admiralty. The slogan, "Determine our own destiny, flowers blooming everywhere" (mingyun zijue, hua kai biandi 命運自決, 花開遍地), spread throughout the occupation sites. ${ }^{83}$ While "autonomy" was generally understood to be within the framework of the Basic Law, "self-determination" was seen as dangerously approaching its borders. Slogans referencing identification with Hong Kong were pervasive throughout the movement, many proclaimed an intimate connection with Hong Kong as "home." Other slogans emphasized the connection of "agency" with democracy. Participants also emphasized the feeling of "ownership" in relation to the occupied zones. ${ }^{84}$

77 Undergrad 2015, 31 .

78 For example, Shah 2014.

79 Undergrad 2015, 18

80 Ibid., 19.

81 The four demands were the repeal of the 8.31 NPC decision, the opening of Civic Square, the resignation of the chief executive and his political reform team, and the adoption of civic nomination. See "Four demands by HKFS," 28 September 2014, http://occupycentral.sayit.mysociety.org/speech/601607. Accessed 27 February 2017.

82 Chow 2014.

83 For a systematic analysis of the slogans, see Veg 2016.

84 Interview with former Undergrad editor B, 30 July 2015 
Affirmations of Hong Kong identity in the movement should therefore not be seen as contradictory with the call for universal suffrage. As an editor of Undergrad put it:

The Umbrella movement was a democratic movement for Hong Kong. The imagined community was Hong Kong. Not democracy in China, or democracy in Hong Kong to promote democracy in China. Martin Lee did not understand this when he said the Umbrella movement was part of the Chinese democracy movement. ${ }^{85}$

In this sense, the Umbrella movement can be seen as the mobilization of Hong Kong defining itself as a civic community around the claim for universal suffrage: for this group of people, democracy and localism are one and the same. This is a well-documented modality of civic nationalism in general, ${ }^{86}$ and in particular in relation to Taiwan. ${ }^{87}$

However, this identification with the Hong Kong community was not seen by all participants as excluding identification with China. True to its own historical background and charter, the HKFS continued to advocate democracy in China and universal suffrage within the Basic Law. In letters sent to Xi Jinping 習近平 on 11 October and to Li Keqiang 李克強 on 15 November, the HKFS emphasized the connection with China, recalling its own historical role in writing to Zhao Ziyang 趙紫陽 in the early 1980s, and in 1989:

In May 1989, one million Hong Kong people took to the streets to support Beijing students, hoping for a more democratic and freer China. Unfortunately, the tanks and gunshots on Tiananmen Square smashed the dreams of countless young people, and even more severely undermined Hong Kong's confidence in democratic reunification ... In fact, we believe democracy is not only Hong Kong's aspiration, it is also the aspiration of today's China. ${ }^{88}$

But, this connection to China is based purely on democratic aspiration and uses none of the ethnic rhetoric favoured by the central government. Nonetheless, it was also criticized by more localist activists in the movement. It defines a less confrontational civic identification with Hong Kong that can still connect to a civic identification with China.

Scholarism, which also played an important role in the Umbrella movement, was not so outspoken on issues of Hong Kong and national identity. According to Joshua Wong, it only half-heartedly endorsed the HKFS idea of sending a delegation to Beijing to meet central leaders (the delegation was prevented from boarding a plane). ${ }^{89}$ He takes a more pragmatic attitude to the question of identity:

My feeling is that having democracy is more important than the question of belonging to China or not ... Hong Kong may become a nation in the future but today it doesn't have the capacity to become one. The starting point of advocating self-determination is that I may have no chance to go to Tiananmen in my whole life. Fifteen years ago, everyone thought China would follow the trend of democracy. That it would either democratize itself or at least allow Hong Kong to

85 Interview with former Undergrad editor A, 25 March 2015.

86 Calhoun 1997, 70-71.

87 Muyard 2012.

88 "Shidai de xuanze, renmin de husheng - zhi Li Keqiang zongli shu" (Choice of the times, call of the people - letter to Premier Li Keqiang), 15 November 2014, http://oclp.hk/index.php?route=occupy/ article_detail\&article_id=303. Accessed 27 February 2017.

89 Wong, Joshua 2015a, 49. 
democratize. That no longer seems likely, so it's time for us to change strategy for universal suffrage. ${ }^{90}$

Most interesting in this analysis is that identification is ultimately subordinate to the claim of democracy. Identity is not an independent claim (in the sense of Hong Kong chauvinism), but conversely it should not be invoked by pan-Chinese nationalists to oppose democratization in Hong Kong. If the only community that is willing to democratize in the foreseeable future is Hong Kong, then Hong Kong is the relevant community to identify with.

After the end of the movement, Joshua Wong began to develop his own views on the future of the pro-democracy movement, in which "localist" thinking began to play a greater role. In an article published in August 2015 in Mingpao, he put forward the idea of a constitutional referendum on the future of post-2047 Hong Kong, since Hongkongers were never consulted before the handover: "If we wish for democratic governance of Hong Kong to continue and successfully overcome the 'second question of the future' in 2047, we must affirm our will for sustainable autonomy (zizhi 自治) now that 'democratic reunification' is bankrupt. To do so, we must set self-determination (zijue) of our future as our goal, the idea that Hong Kong people have the right to decide (jueding 決定) their future, and in this way establish Hong Kong's agency (zhutixing)." ${ }^{11}$ Here, we clearly see the idea of the civic local community previously outlined in Undergrad reformulated as a practical political agenda under the heading of a referendum on selfdetermination, defined not in terms of a reified identity but of a democratic community willing to share its votes. ${ }^{92}$

\section{Conclusion}

While scholarship has largely emphasized that Hongkongers' local identity as it emerged since the 1970 s was complementary rather than contradictory to an identification with the Chinese nation, since approximately 2008, converging sets of material and survey data suggest that younger generations of Hongkongers identify more strongly, sometimes exclusively, with a local community. The June Fourth vigil, traditionally the epitome of "liberal patriotism," has since 2009 gradually been reinvented as the expression of a shared experience by a local community, commemorating Hong Kong's failed democratization rather than the "national tragedy" of 1989. The anti-National Education movement in 2012 crystallized the younger generation's critique of traditional notions of cultural nationalism that were widely shared in the colonial era. The Umbrella movement in 2014 endowed this trend with a distinctly civic dimension: the claim for democracy and universal suffrage

90 Interview with Joshua Wong, 24 November 2015.

91 Wong, Joshua 2015b.

92 Similar themes are echoed in the manifesto of Wong's new party, Demosisto, and Brian Fong's

"Resolution for Hong Kong's future," published a few weeks later. 
became rooted in a local community that affirmed its "agency" and right to "self-determination."

Does this shift signal a deeper break or is it simply a displacement of emphasis that does not question Hong Kong's traditional "dual identity"? This article has tried to disaggregate different strands of the new identity through a twodimensional approach, looking at both the type of identification (cultural/ethnic vs civic) and the framework of reference (pan-Chinese vs localist, see Figure 1). When the new discursive categories of localism, agency, and self-determination first gained currency, they appeared in two distinct formulations: on the one hand connected with a civic community, and on the other as cultural/ethnic affirmations of the difference between Hongkongers and mainlanders. Characteristically, Chin Wan's formulation of local identity, grounded in anti-communism and an affirmation of local culture as the "purest" expression of Chinese culture, is able to connect seamlessly with the traditional pan-Chinese cultural identity. Symmetrically, the civic community of Hong Kong citizens, grounded in the claim for democracy expressed in the June Fourth vigil or even the Umbrella movement, is still able to connect (at least intermittently) with a pan-Chinese community grounded in civic values. Therefore, the most significant aspect of the broader evolution in Hong Kong may not be the tilt towards localism but rather the shift from an ethnic and cultural form of (pan-Chinese) identification, which was a corollary of colonial depoliticization, to a civic-based form of identification grounded in a democratic community. In the 2016 LegCo election, while six candidates from post-Umbrella groups were elected, advocates of (civic) "self-determination" largely prevailed over (ethnocultural) nativists.

In parallel, representations of the pan-Chinese community have become increasingly unavailable to civic discourses of the nation grounded in democracy and universal values, as the Beijing government takes pride in an authoritarian style of governance, which it justifies in terms of cultural exceptionalism, relying heavily on a racialist discourse of blood ties. In this sense, the civic-based expression of a Hong Kong community (Figure 1, group 4) has become less and less compatible with the dominant mode of identification with a greater Chinese nation in cultural-ethnic terms (Figure 1, group 1). Juan Linz and Alfred Stepan used the example of Hong Kong to suggest that democracy is ultimately impossible in a non-sovereign territory if the larger entity remains undemocratic. ${ }^{93}$ Their intuition may provide one explanation for the emergence of "strategic essentialism" in Hong Kong: claiming sovereignty becomes a requisite corollary of claiming democracy. Paradoxically, it may therefore be the (civic) mode of identification rather than the (local) framework of reference that has made the connection between local and national identities, which traditionally were strongly compatible, more and more difficult. 


\title{
Acknowledgment
}

This paper was first presented at the CEFC-HKU workshop, "The boundaries of democracy," on 10 October 2014. I would like to thank all participants for their comments (especially Jean-Philippe Béja, Edmund Cheng, Ming-sho Ho, Ip Iam-chong, Frank Muyard, Wu Jieh-min, and Samson Yuen), Jean-François Dupré, who commented on an early version, and the two anonymous reviewers for their suggestions.

\section{Biographical note}

Sebastian Veg is a professor (directeur d'études) of intellectual history and literature of 20th century China at the School of Advanced Studies in Social Sciences (EHESS), Paris, and an honorary professor at the University of Hong Kong. His interests lie in 20th-century Chinese intellectual history, literature, and political debates, as well as intellectual and cultural debates in Hong Kong.

\begin{abstract}
摘要：根据一般理解, 香港虽然有自己的地方特点, 但同样认同大中华文 化。可是, 近十年, 香港出现了新类型的香港身份认同话语。最近 “本土” 论述经常出现, 甚至 “自决” 需求都浮出水面。那么, 这种论述与 1970 年 代的传统 “香港人” 论有多大差别? 本文试图从两重角度探索本土身份认 同论, 不仅探讨它的认同框架 (地方/大中华), 又分析它的认同方式 (文化族裔认同/公民认同)。通过三个个案一一六四纪念会、2012 年的反国民教 育运动、2014 年的雨伞运动一, 本文区分本土认同的两种类型: 基于政 治与公民 (civic) 的身份认同 (例如学民思潮, 学联的论述), 和基于族裔与 文化 (ethno-cultural) 的身份认同(如陈云等人论述)。如果在过去地方与国 家层次的身份认同不矛盾, 那么最近的冲突来自哪里? 本文提出这样的问 题: 除了中港 (框架) 矛盾之外, 存在于本地公民的民主群体与北京当局促 成的族裔文化民族群体之间的冲突, 是否更加重要?
\end{abstract}

关键词: 香港身份认同; 本土; 公民民族主义; 文化民族主义; 六四悼念会; 雨 伞运动; 反国民教育运动

\section{References}

Calhoun, Craig. 1994. "Social theory and the politics of identity." In Craig Calhoun (ed.), Social Theory and the Politics of Identity. Oxford: Blackwell, 9-36.

Calhoun, Craig. 1997. Nationalism. Buckingham: Open University Press.

Chan, Cheuk-Fan. 2012. "Deyu ji guomin jiaoyu ke yu xiaoxue ge kemu diechuangjiawu” (Moral and national education curriculum is redundant with several primary school curricula), Scholarism Facebook page, 17 September, https://www.facebook.com/Scholarism/posts/474781379220940. Accessed 7 February 2017.

Chan, Elaine, and Joseph Chan. 2013. "Liberal patriotism in Hong Kong." Journal of Contemporary China 23(89), 952-970.

Cheng, Edmund. 2016. "Street politics in a hybrid regime: the diffusion of political activism in postcolonial Hong Kong." The China Quarterly 226, 383-406. 
Cheng, Edmund, and Samson Yuen. 2015a. "Zai bentu yu pushi zhijian de liusi" (June Fourth between universal and local), Mingpao, 13 June.

Cheng, Edmund, and Samson Yuen. 2015b. "Hong Kong's Umbrella protests were more than just a student movement," China File, 1 July, https://www.chinafile.com/reporting-opinion/features/ hong-kongs-umbrella-protests-were-more-just-student-movement. Accessed 7 February 2017.

Chin, Wan. 2011. Xianggang chengbang lun (Theory of the Hong Kong City-state). Hong Kong: Tianchuang/Enrich.

Chin, Wan. 2012. "Xianggang chengbang yu gangren zizhi lun" (The Hong Kong city-state and the theory of self-rule by Hongkongers). Journal of Local Discourse 2011, 179-189.

Chin, Wan. 2013. "Shijian pushi jiazhi: ling ni guopo jiawang" (Practising universal values will destroy your country and ruin your home), Facebook, 15 June, https://www.facebook.com/notes/ wan-chin $/ \% \mathrm{E} 9 \% 99 \% \mathrm{~B} 3 \% \mathrm{E} 9 \% 9 \mathrm{~B} \% \mathrm{~B} 2 \% \mathrm{E} 5 \% \mathrm{AF} \% \mathrm{~A} 6 \% \mathrm{E} 8 \% \mathrm{~B} 8 \% 90 \% \mathrm{E} 6 \% 99 \% \mathrm{AE} \% \mathrm{E} 4 \% \mathrm{~B} 8 \% 96 \%$ E5\%83\%B9\%E5\%80\%BC $\%$ E4\%BB $\% \mathrm{~A} 4 \% \mathrm{E} 4 \% \mathrm{BD} \% \mathrm{~A} 0 \% \mathrm{E} 5 \% 9 \mathrm{C} \% 8 \mathrm{~B} \% \mathrm{E} 7 \% \mathrm{~A} 0 \% \mathrm{~B} 4 \% \mathrm{E} 5 \% \mathrm{AE} \%$ B6\%E4\%BA\%A1/606670522690234. Accessed 7 February 2017.

Chin, Wan. 2015. "A federation for China and Hong Kong," New York Times, 14 June, http://www. nytimes.com/2015/06/15/opinion/a-federation-for-hong-kong-and-china.html.

Chow, Alex. 2014. "Mengxing shike, miandui xianshi" (Time to awaken from the dream and face reality), 28 August, http://www.hkfs.org.hk/2014/08/29/awakening/.

Dikötter, Frank. 2015. The Discourse of Race in Modern China (revised). London: Hurst.

Hsiau, A-Chin. 2005. "Bentuhua - an endeavour for normalizing a would-be nation-state?" In John Makeham and A-Chin Hsiau (eds.), Cultural, Ethnic and Political Nationalism in Contemporary Taiwan. New York: Palgrave, 261-276.

Huang, Liping. 2012. "Xianggang. Zhe yi dai de liusi" (Hong Kong: this generation's June Fourth), iSun Affairs, 5 June, http://chinadigitaltimes.net/chinese/2012/06/香港\%E3\%80\%82這一代的六四/.

Hung, Ho-fung. 2014. "Liusi daonian yiding yao jianchi, ye yao qu-Zhongguohua" (Stick to commemorating June 4th, but also desinicize), Stand News, 3 June, http://vicsforum.blogspot.com/ 2013/06/blog-post_3.html.

Ip, Iam-chong. 2010. "Baoyu yundong: youguan Tianxing matou, Huanghou matou yu bentu xingdong de yanjiu" (The heritage preservation movement: a study on the Star Ferry pier, the Queen's Pier, and Local Action). In Ip Iam-chong, Nostalgia for the Present: The Past and Present State of Cultural Conservation. Hong Kong: Hong Kong Institute of Asia-Pacific Studies, 27-52.

Kan, Flora. 2007. Hong Kong's Chinese History Curriculum from 1945: Politics and Identity. Hong Kong: Hong Kong University Press.

$\mathrm{Ku}$, Agnes Shuk-mei. 2012. "Remaking places and fashioning an opposition discourse: struggle over the Star Ferry Pier and the Queen's Pier in Hong Kong." Environment \& Planning D: Society and Space 30(1), 5-22.

Kuang, Da. 2013. "Chen Yun: Xianggang yimin de xianshi jiaolü" (Chin Wan: the real worry of Hong Kong's immigrants), iSun Affairs 38, 10 January, http://vicsforum.blogspot.fr/2013/01/ blog-post_3165.html, 60-65.

Lam, Wai-man. 2004. Understanding the Political Culture of Hong Kong: The Paradox of Activism and Depoliticization. Armonk, NY: M.E. Sharpe.

Law, Wing-sang. 2009. Collaborative Colonial Power: The Making of the Hong Kong Chinese. Hong Kong: HKU Press.

Law, Wing-sang [An Tu]. 2013. "Aiguo kao: aiguo zhenglun zhong zai si Chen Duxiu" (Patriotic dilemma: reflecting anew on Chen Duxiu among the patriotism controversy), Sunday Mingpao, 16 June, http://vicsforum.blogspot.hk/2013/06/blog-post_7819.html.

Law, Wing-sang [An Tu]. 2014. "Xunzhao bentu ziwo de liusi" (In search of our own local June Fourth), Sunday Mingpao, 15 June.

Lee, Francis, and Joseph M. Chan. 2011. "The June Fourth connection.” In Francis Lee and Joseph M. Chan, Media, Social Mobilization, and Mass Protest in Post-colonial Hong Kong: The Power of a Critical Event. London: Routledge, 184-197. 
Lee, Teng-hui. 2001. "Cibei yu kuanrong" (Mercy and tolerance), 17 November, http://tp.50webs. com/mercy1.htm. Accessed 27 February 2017.

Lee, Yee. 2013. "Cong wu dao you de Xianggang bentu yishi de xingqi" (From inexistence to existence: the rise of Hong Kong's local consciousness), Apple Daily, 20 November, http://hk.apple. nextmedia.com/news/art/20131120/18515717.

Linz, Juan, and Alfred Stepan. 1996. “'Stateness,' nationalism and democratisation.” In Juan Linz and Alfred Stepan, Problems of Democratic Transition and Consolidation. Baltimore: Johns Hopkins University Press, 16-37.

Lui, Tai-lok. 2014. "Fading opportunities. Hong Kong in the context of regional integration." China Perspectives 1, 35-42.

Luk, Bernard Hong-Kay. 1991. "Chinese culture in the Hong Kong curriculum: heritage and colonialism." Comparative Education Review 35(4), 650-668.

Ma, Eric Kit-wai. 1999. Culture, Politics, and Television in Hong Kong. London: Routledge.

Ma, Ka-fai, Leung Man-to and Wong Wai-lun (eds.). Bentu lunshu (Journal of Local Discourse). 2009. Hong Kong: Up Publications.

Ma, Ngok. 2011. "Values change and legitimacy crisis in post-industrial Hong Kong." Asian Survey 51(4), 683-712.

Mathews, Gordon. 1997. "Heunggongyahn: on the past, present, and future of Hong Kong Identity." Bulletin of Concerned Asian Scholars 29(3), 3-13.

Mathews, Gordon, Eric Kit-wai Ma and Tai-lok Lui. 2008. Hong Kong, China: Learning to Belong to a Nation. London: Routledge.

Morris, Paul, and Edward Vickers. 2015. "Schooling, politics, and the construction of identity in Hong Kong: the 2012 'moral and national education' crisis in historical context." Comparative Education 51(3), 305-326.

Muyard, Frank. 2012. "The formation of Taiwan's new national identity since the end of the 1980s." In David Blundell (ed.), Taiwan since Martial Law: Society, Culture, Politics, Economy. Taipei: National Taiwan University Press, 297-366.

Ng, Joyce, Stuart Lau, Jeffie Lam and Tony Cheung. 2015. "Victoria Park lit up at June 4 vigil as 'localist' groups stage alternative rallies," South China Morning Post, 5 June, http://www.scmp. com/news/hong-kong/politics/article/1816344/ hong-kongs-candlelight-vigil-mark-tiananmen-crackdown-gets.

Shah, Aneri. 2014. "The Umbrella movement belongs to everyone who calls Hong Kong home," Quartz, 7 October, http://qz.com/277131/the-umbrella-movement-belongs-to-everyone-who-callshong-kong-home/.

Shulman, Stephen. 2002 "Challenging the civic/ethnic and West/East dichotomies in the study of nationalism." Comparative Political Studies 35(5), 554-585.

Smith, Anthony. 1991. National Identity. Reno, NV: University of Nevada Press.

Survey Research Hong Kong. 1982. "Future of Hong Kong poll," http://documents.tips/download/ link/1982-future-of-hk-poll. Accessed 7 February 2017.

Tai, Yiu-ting Benny. 2013. "Heping zhanzhong' shi bentu de minzhu yundong” (OCLP is a localist democracy movement), Stand News, 22 October, http://oclp.hk/index.php?route=occupy/article_ detail\&article_id $=69$.

Undergrad Editorial Board. 2015. Xianggang minzulun (Hong Kong Nation). Hong Kong: HKUSU.

Veg, Sebastian. 2013. "Hong Kong's enduring identity crisis," The Atlantic, 16 October, http://www. theatlantic.com/china/archive/2013/10/hong-kongs-enduring-identity-crisis/280622/.

Veg, Sebastian. 2015. "Legalistic and utopian: Hong Kong's Umbrella movement." New Left Review 92, 55-73.

Veg, Sebastian. 2016. "Creating a textual public space: slogans and texts from Hong Kong's Umbrella movement.” Journal of Asian Studies 75(3), 673-702.

Vickers, Edward. 2003. In Search of an Identity: The Politics of History as a School Subject in Hong Kong, 1960s-2002. London: Routledge. 
Vickers, Edward. 2011. "Learning to love the motherland: 'national education' in post-retrocession Hong Kong.” In Gotelind Müller (ed.), Designing History in East Asian Textbooks. Identity Politics and Transnational Aspirations. London: Routledge, 85-116.

Vickers, Edward, and Flora Kan. 2003. "The reeducation of Hong Kong: identity, politics, and education in postcolonial Hong Kong." American Asian Review 21(4), 179-228.

Wong, Joshua. 2011a. "Xianggang sheyun yu 89 minyun zhi gongmin kangming" (Civil disobedience in Hong Kong's social movement and in the 1989 democracy movement), 8 April, Joshua Wong's Blog, https://wongchifung.wordpress.com/2011/04/08/香港社運與八九民運之公民抗命/.

Wong, Joshua. 2011b. "Ershi'er zhounian liusi suosi suoxiang" (Thoughts on the 22nd anniversary of June Fourth), 5 June, Joshua Wong's Blog, https://wongchifung.wordpress.com/2011/05/05/二十二 週年六四所思所想/.

Wong, Joshua. 2012. "Weichengnian sheyun zhanshi Huang Zhifeng mimi shouce dujia da gongkai" (Underage social movement fighter Joshua Wong's secret diary: exclusive publication), Mingpao, 21 May.

Wong, Joshua. 2015a. "Scholarism on the march." New Left Review 92, 43-52.

Wong, Joshua. 2015b. "Minzhu yundong xia yibu" (The next step for the democracy movement), Mingpao, 2 August.

Wong, Stan. 2015. "Real estate elite, economic development, and political conflicts in postcolonial Hong Kong." China Review 15(1), 1-38.

Yeung, Linda. 2013. "Liberal studies subject moulds new generation of socially aware youth," South China Morning Post, 1 July, http://www.scmp.com/lifestyle/family-education/article/1271164/ liberal-studies-subject-moulds-new-generation-socially.

Yuen, Samson. 2014. "Under the shadow of China. Beijing's policy towards Hong Kong and Taiwan in comparative perspective." China Perspectives 2, 69-76. 